Volume 13 Number 2, April-June 2019: pp. 151-166. Copyright (c) 2019 FIAT JUSTISIA. Faculty of Law, Lampung University, Bandarlampung, Lampung, Indonesia. ISSN: 1978-5186 | e-ISSN: 2477-6238.Open Access: http://jurnal.fh.unila.ac.id/index.php/fiat

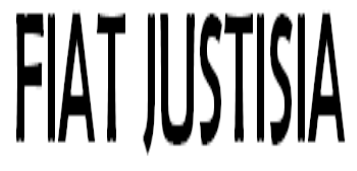

Fiat Justisia is licensed under a Creative Commons Attribution 4.0 International License, which permits unrestricted use, distribution, and reproduction in any medium, provided the original work is properly cited.

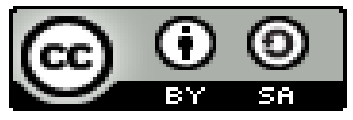

\title{
Prevention and Handling of the Crisis of Financial Systems in Banking Institutions
}

\author{
Zulfi Diane Zaini \\ University of Bandar Lampung, Indonesia \\ zdiane.zaini@yahoo.com \\ Lukmanul Hakim \\ University of Bandar Lampung, Indonesia \\ lukman517422@gmail.com
}

\begin{abstract}
Handling of troubled banks currently carried out has been carried out coordinated by related institutions including the Ministry of Finance, Bank Indonesia, the Financial Services Authority and the Deposit Insurance Corporation, as mandated by Law Number 9 of 2016 concerning Prevention and Handling of the Financial System Crisis where the handling of troubled banks can be more complex and integrated not only the impact of micro and macro. So that the community can maintain its trust in banking institutions and greatly help economic activities, especially banking entrepreneurs. The problems in this research are as follows: 1) How is the Application of the Precautionary Principle in Minimizing the occurrence of Problematic Banks in Indonesia? And; 2) How is Legal Certainty in settlement of Problem Banks in Indonesia?

The research method used to answer the problems in this study is to use a normative legal research approach which is also called theoretical legal research or dogmatic legal research because it does not review the implementation of legal implementation. The results of the research and discussion show that the application of the precautionary principle carried out by these banking institutions can make a very impactful contribution, especially to minimise the occurrence of good problem banks that have systemic or non-systematic impacts. Also, legal certainty in the context of
\end{abstract}


handling this troubled bank has been stated in the PPKSK Law as an attempt to resolve troubled banks.

Keywords: Prevention And Handling Of The Crisis, Financial Systems, Banking Institutions

How to Cite: Zulfi Diane Zaini dan Lukmanul Hakim, "Prevention and Handling of the Crisis of Financial Systems in Banking Institutions", Fiat Justisia, 13 (2), (2019).

DOI: https://doi.org/10.25041/fiatjustisia.v13no2.1567

\section{A. Introduction}

The economic crisis that hit Indonesia a few years ago was not solely due to inequality in the banking system, but various problems faced in the banking sector itself had triggered the crisis. The survey results in various countries concluded that there was a positive correlation between the effectiveness of bank supervision carried out by the supervisory authority and the problems that occurred in the banking sector itself (banking problems). The main cause of wrong bank management comes from poor bank supervision, which ultimately leads to bank failure. Most bank failure cases in Indonesia show that the intervention of bank owners in bank operations and banking fraud committed by bank owners and managers is the main cause of bank bankruptcy, in addition to the impact of the financial crisis that has plagued the Asian region since the middle of the year 1997-1998 ago. Banks are agencies that have a vital role in various activities, for the sake of that support the interests of the group in all lines. Currently, the group cannot be excluded from the bank's financial services institutions, which is no longer a secret that supports the financial affairs of entrepreneurs who want to develop their business. ${ }^{1}$

Banks are financial institutions that are private places, private-owned enterprises, state-owned enterprises, and even groups of authorities. Through operational affairs, credit and various services provided by banks that serve credit needs and launch a deposit system process for all units, both business and non-business sectors. ${ }^{2}$ In facing national economic developments that are always moving fast, competitive and integrated with various increasingly complex challenges, policies in the legal and economic fields are needed. One

\footnotetext{
${ }^{1}$ Lukmanul Hakim, "Analisis Alternatif Penyelesaian Sengketa Antara Pihak Nasabah Dengan Industri Jasa Keuangan Pada Era Otoritas Jasa Keuangan”, Jurnal Keadilan Progresif, 6 (2), (2015), p. 162.

2 Tarsisius Murwaji dan Achmad Hagy Roby, "Edukasi dan Penyehatan Koperasi Melalui Linkage Program Perbankan", Padjadjaran Jurnal Ilmu Hukum, 4 (3), (2017), p. 464 .
} 
of the efforts carried out as a follow-up policy in the field of economic law, Law Number 7 of 1992 concerning Banking was issued (from now on abbreviated as Law No. 7/1992). Furthermore, Law No.7 / 1992 was amended and amended by the issuance of Law Number 10 of 1998 (from now on abbreviated as Law No. 10/1998) concerning Banking. However, as a legal basis for growing banking activities, the regulation still needs to be improved.

Article 3 of the Banking Law explains the business activities of banks as fund collectors and distributors to the public. By the main function of the banking institution itself, Financial Intermediary. The target aims to collect money in the form of inventory, namely savings, time deposits and demand deposits, and the distribution of money to the public in the form of recognition to provide community welfare in the business sector to improve national economic development.

As an agent of trust from the public, it is necessary to implement one of the bank's management principles, namely the fiduciary principle so that in providing loans in the form of bank loans, they can always be guided by the prudential banking principle as stated in article 29 paragraph 2 and 3 of the Banking Act, in the form of provisions needed to take active sustainability and management of the bank in a healthy manner so as to be able to maintain the soundness of banking institutions and automatically maintain the level of public trust. ${ }^{3}$ In line with this, changes were made to Law Number 13 of 1968 (from now on abbreviated to Law No.13 / 1968) concerning the Centre al Bank being Law Number 23 on 1999 (Law No.23 / 1999) concerning Bank Indonesia, and later some of the articles were amended and supplemented by the re-issuance of Law No. 3 of 2004 (Law No. 3/2004) and the last was amended by Law Number 6 of 2009 (hereinafter referred to as BI Law), further emphasizing the position of BI as an independent central bank and having a strong legal basis, so as to realize its objectives in achieving and maintaining stability in the value of the rupiah. After the issuance of Law Number 23 of 1999 in conjunction with Constitution 3 of 2004, the latest Constitution 6 of 2009 about Bank Indonesia, said that Bank Indonesia as an independent State Institution and Bank Indonesia was also declared a Legal Entity.

Bank Indonesia is not only independent of the influence of the Government but also independent of the influence of the legislature, so that the legal standing of Bank Indonesia can be said to be very strong. Also, Bank Indonesia was given the right to set monetary policy. Then proceed with the ratification of constitution 21 of 2011 about the Financial Services Authority, where the Financial Services Authority has a function as Supervisor of Financial Services Institutions in Indonesia today. Also, the government

${ }^{3}$ Lukmanul Hakim, Loc.Cit., p. 162. 
established a Savings Guarantee Agency, which is needed to maintain public trust in the banking sector and minimise the risks that burden the state budget or risks that cause a moral hazard so that a limited guarantee system replaces the guarantee that is very broad in scope.

The Deposit Insurance Corporation (LPS), which is an independent institution formed based on constitution 24 of 2004 about the Deposit Insurance Corporation (LPS regulation) was changed by constitution 7 of 2009. The LPS regulation was promulgated since September 22, 2004, and entered into force 12 months after promulgation, namely September 22, 2005. With the enactment of the LPS Law, LPS began operating since September 22 , 2005. Significant changes in guarantee through LPS were the elimination of blanket guarantees, namely guarantee all bank obligations, without limitation the value becomes a limited guarantee, namely limited guarantees. The application of the precautionary principle to the bank needs to be implemented and implemented not only intended to avoid the occurrence of business risks that will occur at the bank itself, for example a troubled bank or even cause the bank to fail in the end, resulting in a reduced level of public trust in the bank in the future. ${ }^{4}$

The presence of Bank Indonesia, the Financial Services Authority and the Deposit Insurance Corporation, which is always coordinating, is a rule that regulates the cooperation of each institution to work well following its authority. To improve the performance of financial institutions in Indonesia, and to maintain the stability of the banking process. Coordination arranged, in this case, is coordination between OJK and LPS and Bank Indonesia in integrated institutional relations. OJK also coordinates with LPS on a troubled bank that is to restructure the OJK. The form of coordination carried out between OJK and LPS is in the form of information based on an assessment conducted by OJK. LPS can also conduct checks on banks related to their duties, functions, and authority prioritised by coordinating with OJK to minimise the domino effect on banks that have problems or other impacts.

From the description of the background above, there are several problems which consist of; 1) What is the Application of the Precautionary Principle in Minimizing the occurrence of Problematic Banks in Indonesia? And; 2) How is Legal Certainty in settlement of Problem Banks in Indonesia?

\section{B. Method}

This type of research belongs to normative law, which is commonly referred to as theoretical legal research. The definition of normative legal

\footnotetext{
${ }^{4}$ Dahlan Siamat, Manajemen Lembaga Keuangan, Jakarta: Fakultas Ekonomi Universitas Indonesia, (1999), p. 83.
} 
research is done by examining library materials or mere secondary data ${ }^{5}$. This study uses descriptive. According to Abdulkadir ${ }^{6}$ is exposure and aims to obtain an overview of the facts that exist or describe in full about the latest regulation subject matter that apply in certain places that occur in public.

Regarding the problem and approach to the problem used, in principle, this research uses library data sources ${ }^{7}$. While the types of data are:

\section{Minor Data}

Minor data is data there is studying documents related to the issues discussed and studying legislation, and legal books. Data collection activities are carried out through the following stages:

a. Collecting information and data from legal books concerning research problems.

b. Inventorizing data that is relevant to the formulation of the problem by reading, studying, quoting/taking notes, and understanding the meaning;

c. Review the collected data by reviewing the literature and other literature to facilitate the discussion of this research and to determine its relevance to the needs and formulation of the problem.

2. The material of Primary Law

Primary legal materials are legal materials that have binding legal powers such as legislation, the contents of the agreement and other regulations relating to the problems discussed in this study.

3. Secondary Legal Materials

Secondary legal material, namely legal material that can explain primary legal material. Secondary legal materials include books or literature and scientific and non-legal scientific works, government regulations, draft laws, academic texts.

4. Tertiary Legal Materials

Other supporting materials that are related to the main subject matter of the problem, provide clarity on what the information contains, and an explanation of superior and minor regulation material, not what is in the study of legal materials, but can be used as an analysis of the application of legal policies in the field, such as the results of research, bulletins, magazines, articles on the internet and other materials of a nature such as scientific works relating to the problems that will be discussed in this study.

\section{Discussion}

\footnotetext{
${ }^{5}$ Soerjono soekanto dan sri mamuji, Penelitian Hukum Normatif Suatu Tinjauan Singkat, Jakarta: Raja Grafindo Persada, (2010), p.13.

${ }^{6}$ Abdulkadir Muhammad, Hukum dan Penelitian Hukum, Bandung: Citra Aditya Bakti, (2004), p. 50 .

${ }^{7}$ Mukti Fajar dan Yulianto Achmad, Dualisme Penelitian Hukum Normatif dan Empiris, Yogyakarta: Pustaka Pelajar, (2010), pp. 156-158.
} 


\section{Application of the Precautionary Principle in Minimizing the occurrence of Problematic Banks in Indonesia}

Bank practice is a practice that is interrelated between individuals with one another. Bank failures not only cause problems for each bank. However, banks fail to be able to provide company risks. Because the bank provides settlement facilities, the defeat in the banking sector (failed bank) in its order will cause failure in the large business sector (corporate failure) where there are obstacles in settlement facilities ${ }^{8}$. As a result of a failure in this sector can hurt the overall model (systemic risk), bank failure can cause problems in the practice of the bank as a whole and can result in large-scale withdrawal of money against bank fit.

The business carried out in banking activities is a risk-filled business activity (full risk business) because its activities mostly rely on community deposits, both in the form of savings, current accounts and time deposits and if managed properly and prudently will provide substantial benefits. The magnitude of the role of banks in economic activities, so that in carrying out their business activities banking institutions must be supported by a juridical framework and good and strong banking regulations.

Bank Indonesia, as the Center Bank, which is the holder of financial and banking authorities, has the authority to set rules and is responsible for supervising the running of business activities and banking activities. Therefore, policies in the banking sector must be directed at efforts to realise healthy banking. The precautionary principle (prudential banking principle) is a principle or principle that states that bank in realising roles and affairs in the business sector must be careful to guard public money entrusted to the bank. It can be seen in Article 2 of the Banking Law, which states that Indonesian Banking in carrying out its business is based on economic democracy using the principle of prudence.

The provisions in Article 29 paragraph (2), (3) and (4) of the Banking Law also explicitly contain regulatory content regarding the principle of prudence in banking activities. The provisions of Article 29 of the Law concerning Banking stipulate that the Bank must maintain the level of health and carry out activities that do not harm customers or banks so that they can be specifically stated as provisions that are within the scope of guidelines and supervision, meaning provisions regarding the principle of prudence Banking banking is part of bank guidelines and supervision. The regulation of the precautionary principle is also contained in Article 8.

\footnotetext{
${ }^{8}$ Sunarsip dan Suyono Salam, "Analisa atas Deregulasi, Krisis, dan Restrukturisasi Perbankan Di Indonesia", Jurnal Keuangan Publik, I (1), (2003), Badan Pendidikan dan Pelatihan Keuangan, Departemen Keuangan Republik Indonesia.
} 
The implementation of the precautionary principle is the most important thing in maintaining the soundness of the bank and can minimise the risk of bank problems. A bank is said to be problematic if the bank experiences a difficulty that can endanger its business continuity, for example, the bank's business conditions deteriorate with a marked decline in the capital, asset quality, liquidity, etc. These are due to the lack of implementation by the prudential principle and sound banking principles. The problematic bank can be classified into two parts, namely:

a. Structurally problematic banks, namely banks that experience very severe conditions and can be threatened at any time. The characteristics of banks that fall into this category include the quality of unhealthy earning assets, experiencing substantial losses and bad liquidations. This situation is usually caused by the owner's involvement in management, which can be seen from the amount of credit given to groups or groups of owners.

b. Banks that have non-structural problems, which fall into this category, usually with the characteristics of the owners not so much interfere in management and realise their mistakes. And even though banks in conditions of profitability tend to deteriorate, but bank capital is still sufficient to provide minimum capital. This category of banks has a low or unhealthy level of health. ${ }^{9}$

Article 37 paragraph (1) of the Banking Law stipulates the steps that need to be taken against troubled banks so that there is no revocation of business licenses and liquidity actions. It is done to maintain or save the bank as an institution of public trust. Then the banking institution needs to take protective measures indirectly by applying the Prudential Principle, the Lending Maximum Limit (LLL), the obligation to announce the balance sheet and calculation of profit, merger, consolidation and bank acquisition.

The importance of the application of the precautionary principle is one of the efforts to protect banking institutions indirectly considering to maintain public trust in the intermediary institutions so that the community continues to grow its trust. So that banks continue to grow and develop in their business. In addition to the application of the precautionary principle in the context of lending, it is also necessary to pay attention to the existence of a current reference limit for maximum credit so that it does not cause problems at the bank's health level so that it does not become a problem in the bank's soundness crediting constitution.

Precautionary principle is a principle that confirms that banks in carrying out business activities both in collecting funds especially in the distribution of

\footnotetext{
${ }^{9}$ Rachmadi Usman, Aspek-aspek Hukum Perbankan di Indonesia, Jakarta: Gramedia Pustaka Utama, (2001), p.143.
} 
funds to the public must be very careful because they remember that the funds originating are partly from the community so that the bank itself must maintain the soundness of the bank so that public trust can continue to grow. The purpose of this precautionary principle is that the bank is always in a healthy state to run its business well and comply with the provisions and legal norms that apply in the banking world and minimise the occurrence of good problem banks that have systemic or non-systemic impacts. Based on the description above, it can be concluded that the importance of the application of the precautionary principle in banking institutions as an indirect protection effort and to maintain the level of public trust in the banking institutions themselves to minimise the occurrence of problem banks in the constitution in banking institutions.

\section{Legal Certainty in settlement of Problem Banks in Indonesia}

When talking about legal certainty, especially Indonesia is a country sourced from the constitution which has been mandated in the 1945 Constitution, which means that Indonesia is a coordinated rule state that must be sourced from the provisions in force in Indonesia, where we can apply justice and legal certainty ${ }^{10}$. Constitutional provisions are needed to ensure orderliness and safety in the most important banking sector, which is applied in daily banking activities. As confirmed in Article 1, paragraph 3 Amendments to the 1945 Constitution.

The relationship between legal certainty in settlement of troubled banks has an important connection with the development and the business sector in which it supports economic development in particular. The strategy contained in banking today is comprehensive, transparent, accountable, and contains legal certainty. The dilemma in financial institutions, especially banks, must be prevented and dealt with obstacles and distrust from public institutions, especially in bank assistance, which must be more careful because banks must protect a sound and stable financial system. The legal framework that can become the basis of the implementation of the bank's main functions as a whole. Banks are problem banks (troubled banks) problem, namely:

a. Banks that have a high ratio or non-current credit ratio when compared to their capital;

b. The Bank, from the results of the examination of the value of Capital, Asset, Management, Earning, and Liquidity, is commonly known as the term (CAMEL) it is in the fourth position (unhealthy) or five (unhealthy) on the list of conditions of the bank; the assessment is not disseminated to the public; problem banks will be checked more often than healthy

10 Zulfi Diane Zaini, Independensi Bank Indonesia dan Penyelesaian Bank Bermasalah, Bandung: Keni Media, (2012), p. 41. 
banks. In the framework of resolving a troubled bank, Bank Restructuring can be carried out in the context of special supervision carried out on Banks experiencing difficulties.

In this case, the OJK asks Shareholders to take action to increase capital, replace the management (Board of Commissioners / Directors). While to the Bank, OJK requests the Bank to write off bad credit/financing, carry out mergers or consolidations, sell banks (carried out by other parties), submit management of activities to other parties, and sell part / all of the assets. If restructuring measures cannot overcome the Bank's difficulties; and / or according to the OJK's assessment, the condition of a Bank may endanger the banking system, the OJK (the bank no systemic impact) or joint Committee (systemic impact bank) determines it as a Failed Bank and submits its handling to LPS. Public trust in a national company is one of the keys to protecting the stability of a bank company so that the crisis does not happen again. This trust can be obtained by the existence of legal protection in bank policies and controls and saving bank customer savings to increase business continuity the bank in a healthy manner. The business continuity of the bank can protect the security of savings and grow the function of the bank as a collector of development funds and banking services. If the bank runs out of trust from the community so that the bank's business continuity cannot be re-implemented, the bank becomes a Failed Bank, which results in the revocation of the administrative permit. Therefore, both bank owners and employees and various authorities involved in controlling and reviewing banks must join forces to establish public confidence in the bank.

Also, in the framework of legal certainty in the supervision of banking institutions so as not to have an impact on troubled banks, both those that have systemic impacts or not. The supervisory institution groups several banks with systemic impacts based on assets. This data is obtained by sorting the assets of the 15 largest banks at the end of 2018 in Indonesia:

a. BRI Rp 1.126,2 trillion

b. Bank Mandiri Rp 1.124,7 trillion

c. BCA Rp 750,3 trillion

d. BNI Rp 709,33 trillion

e. Bank CIMB Niaga Rp 266,3 trillion

f. BTN 261,36 trillion

g. Bank Panin Rp 200,99 trillion

h. Bank Danamon Rp 178,25 trillion

i. Bank Maybank Indonesia Rp 173,25 trillion

j. Bank OCBC NISP Rp 153,8trillion

k. Bank Permata Rp 148,09 trillion

1. Bank of Tokyo Mitsubishi Rp 147,01 trillion

m. Bank BJB Rp 108,4 trillion 
n. HSBC Indonesia Rp 101,01 trillion

o. Bank Bukopin Rp 100,8 trillion

After looking at the data above, it is necessary to supervise banks that have large amounts of assets so that the systemic bank does not occur in the future. With the coordination of related institutions such as the OJK, BI, LPS and the Ministry of Finance, expected to guard and minimise events problem banks. The mechanism of coordination carried out by related institutions to create and maintain financial the related, and effective stability method became increasingly important after the emergence of tensions in 2008. Indonesia continues to formulate and carry out important rules in the economic field, including the preparation of regulations for the Prevention and Handling of the Financial System Crisis as the main rule for agencies to cooperate in maintaining and stabilising financial models to create legal certainty. This regulation stipulates existing regulations and policies for the prevention and handling of financial system crises, especially for cases that cannot be handled privately by the institution by the authority. With the enactment of constitutional 9 of 2016 about the Prevention and Handling of the Financial System Crisis, it became a legal basis for handling the crisis both micro and micro.

Furthermore, in the regulation, a Financial System Stability Committee was formed, which included:

a. Coordinating observation model stability,

b. Handling of financial model crises, and

c. Handling systemic bank question, both in conditions of normal financial system stability and financial model crisis conditions.

The Financial System Stability Committee occurs starting from the Minister of Finance, the Governor of the Central Bank, the Chairman of the Board of Commissioners of the Financial Services Authority, and the Chairperson of the Board of Commissioners of the Deposit Insurance. In the condition of the financial system crisis, if there is a problem in the banking sector that endangers the national economy, the President based on the recommendation The Financial System Stability Committee can decide on the plan for bank restructuring by the Deposit Insurance Corporation. Through this plan, the Deposit Insurance Corporation handles the cases of banks, both with impacted banks and Non-System Banks.

If sourced from the results of bank supervision conducted by the OJK, a bank is found to have a problem, then the bank is categorised as a potentially problematic bank and furthermore intensive supervision is carried out. OJK determines the Bank's status in Intensive Supervision if a bank fulfils one or more of the following criteria has a predicate of being unhealthy or unhealthy, have a case and problem-solving originating from the overall risk assessment (the entire risk), there is an excess and the Legal Lending Limit (LLL), there 
is a violation of the Net Open Position (PDN), GWM Rupiah GWM) equal to or greater than the ratio set for GWM The bank but has fundamental liquidity problems, has fundamental profitability problems, has non-performing loans are more than $5 \%$ of total loans.

If based on the results of intensive supervision, the condition of the bank improves, the bank is routinely or normally supervised. However, if based on intensive supervision, the condition of the bank deteriorates, the OJK conducts Special Surveillance. Arrangements regarding Handling of Systemic Bank Solvability Problems are regulated from Article 21 to Article 29 of constitution 9 of 2016 about Prevention and Handling of the Financial System Crisis, including:

\section{Article 21 UU PPKSK :}

1) The authority of the OJK to handle solvability issues, including ensuring the implementation of the handling plan.

2) OJK with LPS prepares to handle solvability issues as referred to in paragraph (1).

3) If what is meant in paragraph (1) the condition is increasingly worrisome, the OJK requires LPS to be able to grow stronger to prepare for the action of Banks with Systemic Impacts.

4) OJK prepares for action and prepares with LPS for:

a. Require the Board of Directors of the Bank to maintain the condition of assets and grow the level of liability of the Systemic Bank materially;

b. b. Require Bank directors to carry out the transfer of assets and dependents for Systemic Banks; and

c. Providing marketing of assets and dependents and providing prospective recipients to conduct Fit and proper tests if dependents are to be replaced.

5) OJK holds meetings that are formed by the Financial System Stability Committee accompanied by suggestions for problems.

6) Establish steps in handling systemic banks.

7) Decisions dealing with the problems of handling the Systemic Bank, as stated in paragraph (6) are carried out with:

a. Decide to submit the bank to LPS; and

b. Making decisions made by the Minister of Finance, Governor of Bank Indonesia, and Chairperson of the OJK Board of Commissioners by their authority.

8) Rules for the enforcement of Systemic Bank problems as referred to in paragraph (1) and preparing the handling of Systemic Banks as referred to in paragraph (2) which have been included in POJK. 


\section{Article 22 UU PPKSK :}

1) Control of Bank Systemic issues by LPS is carried out as follows:

a. Exchange dependents to recipient banks;

b. Exchange dependents to Intermediary Banks; or

c. Commence prosecution by LPS regulations.

2) Rules for the problem of procedures for controlling Systemic Bank issues as stipulated in paragraph (1) of the LPS Regulation.

\section{Article 23 UU PPKSK :}

The transfer of part of all Systemic Bank dependents to recipient Banks regulated in Article 22 paragraph (1) letter a or to Intermediary Banks as referred to in Article 22 paragraph (1) letter b, the authority of LPS is as follows:

1) Take decisions on the types of dependents of the Systemic Bank to be transferred;

2) Transferring Systemic Bank dependents by the criteria referred to in letter a to the recipient Bank or Intermediary Bank by the difference such as the systemic Bank's assets and dependents to be transferred; and

3) Organising authority as stipulated in the regulations of LPS.

\section{Article 24 UU PPKSK :}

1) Transfer of wealth and dependents by LPS;

2) Transfer as referred to in paragraph 1 according to the license to carry out certain activities.

3) This transfer referred to in paragraph (2) is by implementing regulations according to regulations.

4) After transferring the assets and dependents of the Systemic Bank to the recipient Bank and Intermediary Bank, LPS requests the OJK to revoke the bank's administrative permit.

5) LPS conduct a liquidation process against a Bank whose license has been revoked following paragraph 4 of the LPS regulation

\section{Article 25 UU PPKSK :}

1) Establishment of Intermediary Banks by LPS by Article 22 paragraph (1) letter $b$ to transfer bank assets and dependents.

2) Establishment of Intermediary Banks by LPS as referred to in paragraph (1) as referring to the Limited Liability Company Law.

a. Giving OJK permission to Intermediary Bank as referred to in paragraph (1) in 2 (two) stages:

b. Preparing Bank Establishment; and

c. Preparing business licenses listed in letter a that have been completed. 
3) Permission in paragraph (3) letter is given after fulfilling the requirements:

a. Business activities are based on the articles of association;

b. Capital deposits are regulated in the latest limited liability company regulations; and

c. Projecting governance, management and human resources.

4) Granting a business permit in paragraph (3) letter b is given after fulfilling the requirements:

a. Dependents on providing capital and meetings are carried out by the organisational structure and

b. Managing human resources.

5) OJK conducts fit and proper tests of Intermediary Bank management based on the provisions.

6) Intermediary Banks conduct business activities as follows:

a. Submission of reports to OJK; and

b. Fulfilment of requirements based on the principle of prudence.

\section{Article 26 UU PPKSK :}

1) Article 22 paragraph (1) letter b says that for the transfer of dependents by LPS.

2) LPS does not apply to the Limited Liability Company Law.

3) The Financial Services Authority grants the Intermediary Bank permission as referred to in paragraph (1) in 2 (two) stages:

a. Implementation of establishing a bank; and

b. Business permit preparation.

4) In paragraph (3) letter a is permitted with the following conditions:

a. Bank business activities are regulated in the Articles of Association;

b. Capital obligations regulated by the PT Law; and

c. Good management and human resources management.

5) Granting business licenses by looking at factors:

a. Dependents on the provision of minimum commercial bank capital;

b. Board of Directors; and

c. Management of human resource management. Fit and proper test by OJK.

6) Intermediary bank business activities:

a. Report the reports; and

b. Implementation of the application of the precautionary principle.

\section{Article 27 UU PPKSK :}

1) Handling the problem in article 22 comes from the wealth of LPS. 
2) LPS and Systemic Bank solvability as referred to in paragraph (1), LPS:

a. Market state securities through the market; and

b. Get a loan.

3) LPS markets Government Securities by Bank Indonesia as referred to in paragraph (2) letter a which will be decided by the Financial System Stability Committee.

4) Based on paragraph (3), Bank Indonesia purchases Government Securities originating from committee decisions.

\section{Article 28 UU PPKSK :}

1) The proceeds of Intermediary Bank sales are added to the results of Systemic Bank liquidations that have been dealt with by the issue issued by LPS to deal with problem banks.

2) Dependent marketing differences from the marketing results of the Intermediary Bank are added to the results of the liquidation of the Systemic Bank that has been dealt with the problem and funds issued by the LPS.

\section{Article 29 UU PPKSK :}

LPS took six months and submitted a report on role growth.

Based on this description, it was concluded that the regulation in dealing with this troubled bank had been carried out with the issuance of the PPKSK Law by taking into account the composition of impacts affecting systemic and non-systemic models both micro and macro scale to provide legal certainty and maintain the level of public trust as depositors money. Also, the establishment of a financial system stability committee consisting of the Ministry of Finance, OJK, BI and LPS is expected to be good coordination so that banking institutions can continue to maintain their level of health.

\section{Conclusion}

Source the results and discussion, the conclusions from this research as follows:

1. Application of the precautionary principle is an indirect effort carried out bank company to eliminate the event of troubled banks as one of the efforts of banking institutions by implementing the principles of $5 \mathrm{c}$ and $4 \mathrm{p}$ in maintaining the level of public trust that has entrusted their funds to banking institutions.

2. Legal certainty in handling troubled banks is an effort of the government and related institutions to maintain the soundness of banks, both troubled banks and banks, which are still in good health so that legal certainty in handling troubled banks can be resolved properly. 


\section{Recommendation}

It is expected that relevant institutions, especially Financial Authority, Bank Indonesia, the Deposit guarantor and the Ministry of Finance can continue to integrate specifically in the prevention and handling of crises so that there are no more problems regarding the crisis that has struck some time ago.

\section{A. Book}

\section{Bibliography}

Muhammad, Abdulkadir. (2004). Hukum dan Penelitian Hukum. Bandung: Citra Aditya Bakti.

Mukti Fajar dan Yulianto Achmad. (2010). Dualisme Penelitian Hukum Normatif dan Empiris. Yogyakarta: Pustaka Pelajar.

Siamat, Dahlan. (1999). Manajemen Lembaga Keuangan. Jakarta: Fakultas Ekonomi Universitas Indonesia.

Soerjono soekanto dan Sri Mamuji. (2010). Penelitian Hukum Normatif Suatu Tinjauan Singkat. Jakarta: Raja Grafindo Persada.

Usman, Rachmadi. (2001). Aspek-aspek Hukum Perbankan di Indonesia. Jakarta: Gramedia Pustaka Utama.

Zaini, Zulfi Diane. (2012). Independensi Bank Indonesia dan Penyelesaian Bank Bermasalah. Bandung: Keni Media.

\section{B. Journal}

Lukmanul Hakim, "Analisis Alternatif Penyelesaian Sengketa Antara Pihak Nasabah Dengan Industri Jasa Keuangan Pada Era Otoritas Jasa Keuangan”, Jurnal Keadilan Progresif, 6 (2), (2015).

Sunarsip dan Suyono Salam, "Analisa atas Deregulasi, Krisis, dan Restrukturisasi Perbankan Di Indonesia", Jurnal Keuangan Publik, I (1), (2003), Badan Pendidikan dan Pelatihan Keuangan, Departemen Keuangan Republik Indonesia.

Tarsisius Murwaji dan Achmad Hagy Roby, "Edukasi dan Penyehatan Koperasi Melalui Linkage Program Perbankan", Padjadjaran Jurnal Ilmu Hukum, 4 (3), (2017), https://doi.org/10.22304/pjih.v4n3.a2 .

\section{Regulations}

Law Number 21 of 2011 on Financial Services Authority.

Law Number 6 of 2009 on Indonesia Bank.

Law Number 7 of 1992 Jo Law Number 10 of 1998 on Banking.

Law Number 7 of 2009 on Deposit Insurance Agency.

Law Number 9 of 2016 on Prevention and Handling of the Financial System Crisis. 
The Constitution of the Republic of Indonesia 1945 (Fourth Amendment). 